\title{
Influence of the COVID-19 Pandemic on the Change in Volume and Spatial Structure of the Tourist Flow in Finland and Estonia in 2020
}

\author{
I. A. Ivanov ${ }^{a, *}$, E. S. Golomidova ${ }^{b, * *}$, and N. K. Terenina ${ }^{a, * * *}$ \\ ${ }^{a}$ Pskov State University, Pskov, Russia \\ ${ }^{b}$ Committee for the Implementation of Cross-Border Cooperation and Tourism Programs, \\ Pskov City Administration, Pskov, Russia \\ *e-mail:ii60@bk.ru \\ **e-mail: golomidova_lena@mail.ru \\ ***e-mail:brazelon@yandex.ru \\ Received October 16, 2020; revised December 29, 2020; accepted April 21, 2021
}

\begin{abstract}
International tourism was among the sectors of the global economy most affected by the COVID-19 pandemic. The aim of the study is to identify the differences in the dynamics of the tourist flow in Finland and Estonia during the first eight months of 2020 compared to 2019, as well as changes in the structure of the inbound tourist flow to these countries. The particular interest in studying tourist flows in Finland and Estonia stems from the fact that over the past two decades, they were among the top ten countries in the world in terms of the volume of outbound tourism by Russians, as well as among the leaders in this indicator among European Union countries, which is directly related to their neighboring position with Russia. Tourism in Estonia and Finland went through a rather difficult period of spring quarantine, and its recovery in the summer began with domestic tourism. There has also been an increase in the inbound tourist flow. At the same time, the best dynamics was demonstrated by the flow of tourists from neighboring countries that are EU members, the border with which for tourists was already partially open in summer 2020 . The adjacent territories of neighboring countries are part of cross-border tourist and recreational regions, within which tourist flows have been recovering faster than tourist exchange with other, geographically more remote states. This conclusion gives hope for a fairly quick recovery of cross-border tourist exchange between Russia and neighboring countries after the postpandemic opening of borders.
\end{abstract}

Keywords: crisis, international tourism, domestic tourism, tourist flow, tourist exchange, cross-border, crossborder tourist and recreational regions

DOI: $10.1134 / \mathrm{S} 2079970521030059$

\section{INTRODUCTION AND FORMULATION OF THE PROBLEM}

Tourism in 2020 was one of the first things hit by the COVID-19 pandemic. The closing of borders and almost complete cessation of international traffic in the second half of March, which affected almost all countries, shook the very foundations of international tourism. The current crisis is the most serious in the history of international tourism. It started abruptly and quickly became global. Exit from the crisis is impeded not only by the difficult situation in related industries (primarily in the transport industries, air transportation, and hotel business) and continuing restrictions on border crossing, but also by people's fear of becoming infected during a tourist trip.

However, international tourism is gradually recovering from the sharp decline. The restarting of tourism is taking place in a controlled manner: the authorities, as a rule, determine not only where their citizens can go on vacation, but also which citizens of which countries will be allowed to enter the country for tourist purposes. It is on this background that the demand for domestic tourism is increasing. The desire to relax outside of the home is gradually overcoming the fear. The tourism recovery phenomenon is of scientific interest for studying this problem.

The aim of the study is to identify the consequences of the COVID-19 pandemic on the dynamics in 2020 and the spatial structure of tourism in Finland and Estonia, i.e., countries that were previously among the top ten for tourist exchange with Russia due to their neighboring position. 


\section{REVIEW OF EARLIER STUDIES}

The crisis triggered by the COVID-19 pandemic has affected the entire world and all areas of life. More and more publications are devoted to analyzing the changes that have occurred. Thus, N.V. Zubarevich and S.G. Safronov (2020) write about the peculiarities of Russian regions' exit from the acute phase of the crisis. The authors conclude that the current crisis is primarily one in the service sector, triggered both by the imposed quarantine restrictions (an institutional factor) and the ensuing drop in demand. Tourism, primarily international, is among the sectors of the economy most affected by the pandemic. The impact of the COVID-19 pandemic on the development of tourism is studied by S.A. Butorov (2020), E.G. Kropinova and K. Stankus (2020), E.I. Makrinova et al. (2020), G.A. Simonyan and A.A. Saryan (2020), E.G. Telicheva and V.A. Chernova (2020), and E.G. Leonidova (2020).

Foreign researchers are also interested in this problem, but so far such studies are few. The methodology applied somewhat differs from that proposed in our study. Polish researchers B. Korinth and R. Ranasinghe (2020) present the results of an analysis of changes in tourist traffic based on indirect indicators: the number of flights and percentage of occupancy of accommodation facilities in certain large Polish cities. A study by South African authors C.M. Rogerson and J.M. Rogerson (2020) is based on a sociological survey of tourism industry representatives. Ukrainian researcher Z.A. Atamanchuk (2020) conducted a comparative analysis of the plans of various tourist-attractive countries to restore tourism.

On a separate note, it is necessary to highlight studies that compare the consequences of the current tourism crisis with previous ones. Romanian researchers M. Daniela and T. Smaranda (2020) showed that over the past 20 years, the total number of tourist arrivals globally has decreased thrice: in 2001 after the terrorist attack in New York (a drop of $-1 \%$ compared to the previous year), in 2003 due to sanitary restrictions associated with the outbreak of severe acute respiratory syndrome (SARS) in China and other countries (a drop of $-0.9 \%$ compared to the previous year), and in 2009 due to the global economic crisis (a drop of $-4 \%$ compared to the previous year). This indicates that international tourism is usually relatively resilient to various external influences. However, in 2020, there was a sharp decline in international tourism, which had no analogs since the Second World War, when movement across state borders was also severely restricted. According to preliminary UNWTO estimates, ${ }^{1}$ in January-August 2020, the decrease in the number of international tourist arrivals globally was $70 \%$.

\footnotetext{
${ }^{1}$ UNWTO World Tourism Barometer. https://www.unwto.org/ barometer. Accessed October 28, 2020.
}

The most acute period of the international tourism crisis in most countries was observed in April-May 2020, after which recovery began, associated with the lifting of some of the restrictions on travel. The topic of restoration of the tourism industry is now becoming extremely relevant, already covered by many publications. For example, I.V. Loguntsova (2020) suggests that domestic tourism will be the first industry in Russia to recover, and the demand for budget travel will increase. The main incentive for the recovery of tourist flows is the accumulation of deferred demand. A similar position is expressed in a number of publications that analyze the current situation in tourism and assesses the prospects for its development in Russia and the world, taking into account the changes in the tourism market that occurred during the pandemic (e.g., (Leushina and Zotova, 2020; Linguryan and Kalinkina, 2020; Polukhina, 2020; Rysaeva and Kabirov, 2020; Chimiris, 2020)).

At the same time, little attention is paid to the pandemic's impact on the prospects for cross-border tourism. Cross-border tourism plays an important role in the socioeconomic development of Russia's border areas, which usually have a relatively low level of socioeconomic development, including because of their peripheral position. This also applies to the border areas of Russia's Northwestern Federal District, in particular, the Republic of Karelia and Pskov Oblast. These two regions are betting on the development of cross-border tourism with neighboring countries, namely, with Finland, Estonia and Latvia, discussed in many publications (e.g., (Manakov et al., 2020; Manakov and Golomidova, 2018; Stepanova, 2014, 2019; Stepanova and Shulepov, 2016)).

Finland and Estonia have been among the top ten countries in terms of the outbound tourist flow of Russians for at least the last two decades, which is explained by their proximity to Russia, due to which powerful cross-border tourist flows are formed (Manakov and Ivanov, 2019). Previous studies on the geography of tourism in Finland and Estonia (Chuchenkova, 2019; Manakov et al., 2020; Manakov et al., 2019) showed that a significant part of tourist flows to these countries is generated in territories adjacent to neighboring countries, where cross-border tourist and recreational regions (CTRR) are formed (Golomidova, 2018; Kropinova, 2016; Manakov and Golomidova, 2018). In addition to tourist and recreational regions forming on the border with Russia, CTRR are being created on the border territories of these countries with other neighbors. And whereas during the COVID-19 pandemic, the borders of these two countries with Russia were almost completely closed to organized tourism, there was still a tourist flow from the EU countries, albeit much smaller than before the pandemic was announced. 


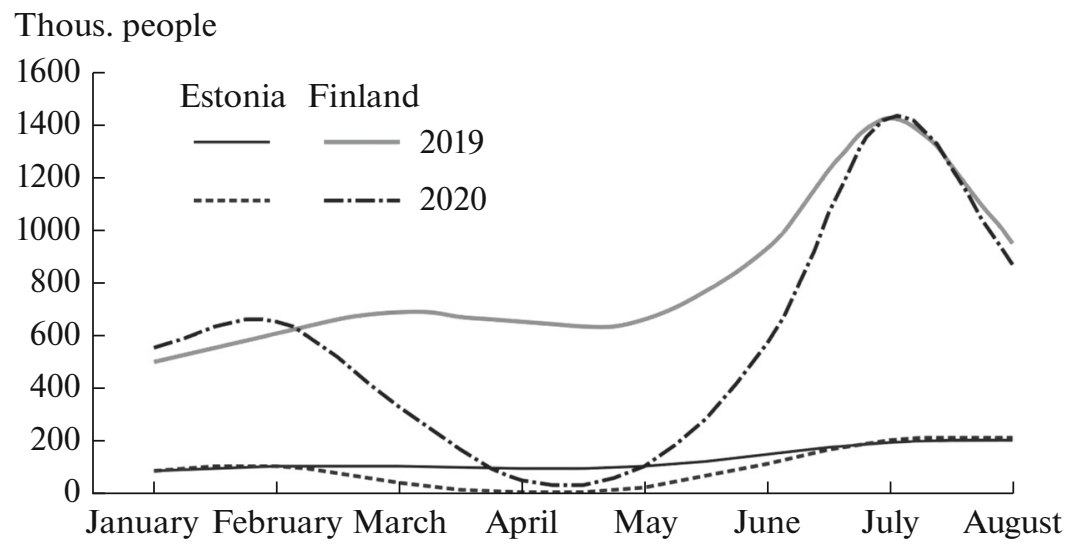

Fig. 1. Comparison of dynamics of internal tourist flow in Finland and Estonia for eight months 2019 and 2020.

\section{RESULTS AND DISCUSSION}

The study is based on government tourism statistics presented on the official statistics websites of Finland and Estonia. ${ }^{2}$ Preliminary data for 2020 were used.

Before the announcement of the pandemic, Finland and Estonia were among the countries receiving the largest tourist flows of Russian citizens. By the beginning of the study period in 2018, Finland ranked third in the world in the number of trips by Russian tourists, and Estonia, seventh. Finland and Estonia were the leaders in receiving Russian tourists among EU countries (Loguntsova, 2020). This allows us to take a special look at changes in the volume and structure of tourist flows in these countries, which have become a consequence of the COVID-19 pandemic. Below we present a comparative analysis of the dynamics of domestic and inbound tourist flows in these two countries for the first eight months of 2019 and 2020.

The graph in Fig. 1 shows the dynamics of the domestic tourist flow in Finland and Estonia by month in 2019 and 2020. Clearly, there was a sharp decrease in domestic tourist flow in April 2020 due to the introduction of quarantine measures in both countries. However, by July, due to the gradual easing of restrictive measures, there has been a recovery in domestic tourist flow, and the figures for July 2020 in both countries were even slightly higher than those of July 2019. In August, this level also generally remained the same. There are two reasons for this. First, during the quarantine period there was deferred demand for vacation. Second, some countries of departure traditional for Finnish and Estonian citizens were still

\footnotetext{
${ }^{2}$ Eesti statistika. Statistical database: Economy. http:/ /pub.stat.ee/px-web.2001/I_Databas/Economy/databasetree. asp. Accessed September 25, 2020; Visit Finland. Statistics Service Rudolf. http://visitfinland.stat.fi/PXWeb/pxweb/en/VisitFinland/. Accessed September 25, 2020; Tõhusam piirihaldusaastateks 2016-2020. https://www.siseministeerium.ee/ sites/ default/files/dokumendid/STAK/2016/programm_h_tohusam_piirihaldus.pdf. Accessed September 25, 2020.
}

closed to tourists (e.g., the Russian Federation) or transport links with them had not been fully restored (e.g., Spain and Italy), or upon return, tourists were required to take a COVID-19 test and then quarantine. All this significantly reduced the number of Finnish and Estonian citizens traveling abroad and stimulated domestic tourism.

Figure 2 shows the change in structure of the inbound tourist flow to Estonia in the first eight months of 2020 versus the same period in 2019. Four key groups of inbound tourist flows are indicated: from Finland and Latvia, other countries of the Baltic region, and other countries.

After the almost complete suspension of international tourism in April and May 2020, inbound tourist traffic began to gradually recover. The fastest to recover almost to the previous level was the tourist flow from Latvia, a country neighboring Estonia, which has close cultural and economic ties (in July 2020, 18600 tourists; in July 2019, 196000). To a lesser extent, there was recovery of the largest inbound tourist flow to Estonia from Finland: in July 2020 it was $40 \%$ less (81000 tourists; in July 2019, 137000).

Among the Baltic region countries, only the tourist flow from Lithuania quickly recovered to the 2019 level (it is not shown separately on the graph, but its indicators in July and August 2020 are even slightly higher than those in 2019: 10300 and 12600 tourists, which was half of all tourists from the other Baltic region countries). In August 2020, the structure of flows was almost the same as in July 2020, but the tourist flow from Finland decreased by half, while those from Latvia and Lithuania slightly increased. Tourist flows from other countries are recovering extremely slowly, almost exclusively at the expense of EU countries due to restrictions on entry. On the whole, by August, the volume of foreign inbound traffic to Estonia recovered by almost half.

The diagrams in Fig. 3, constructed in analogy with Fig. 2, show the change in structure of the inbound 


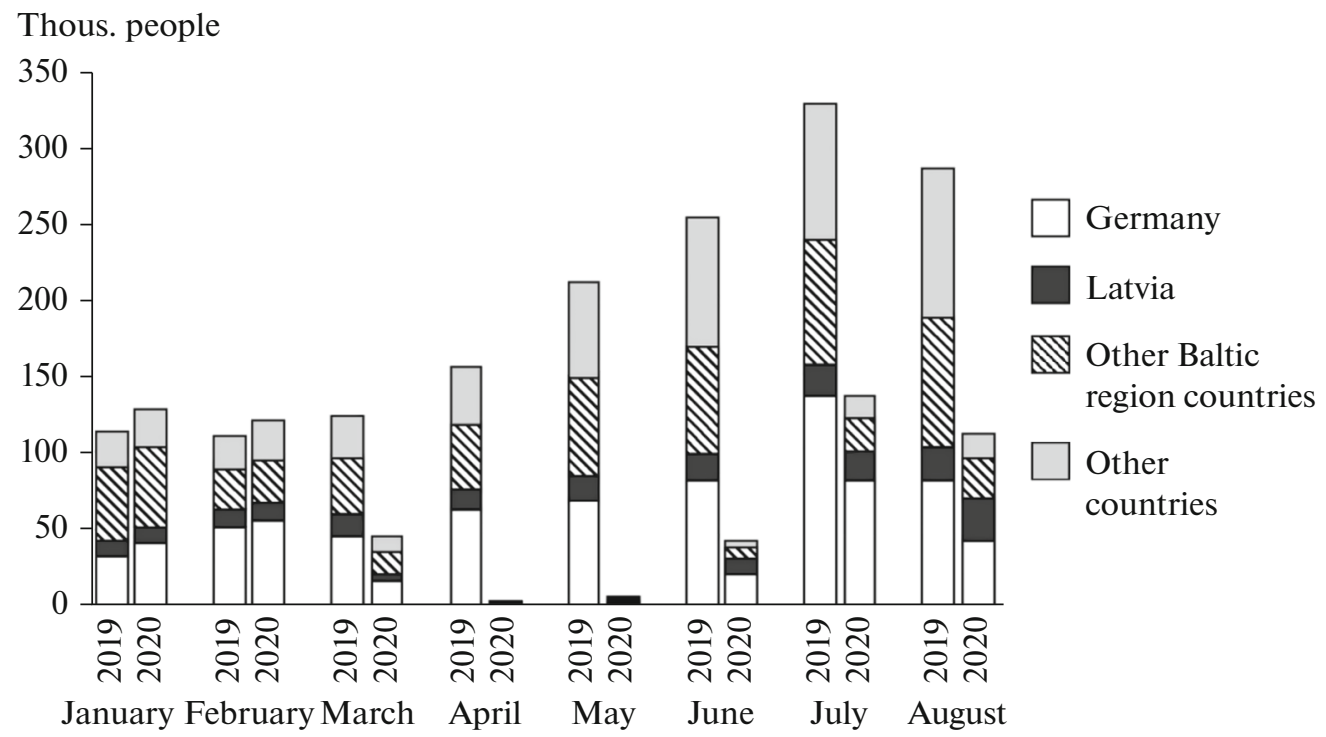

Fig. 2. Changes in structure of inbound tourist flow to Estonia in first eight months of 2020 compared to same period of 2019.

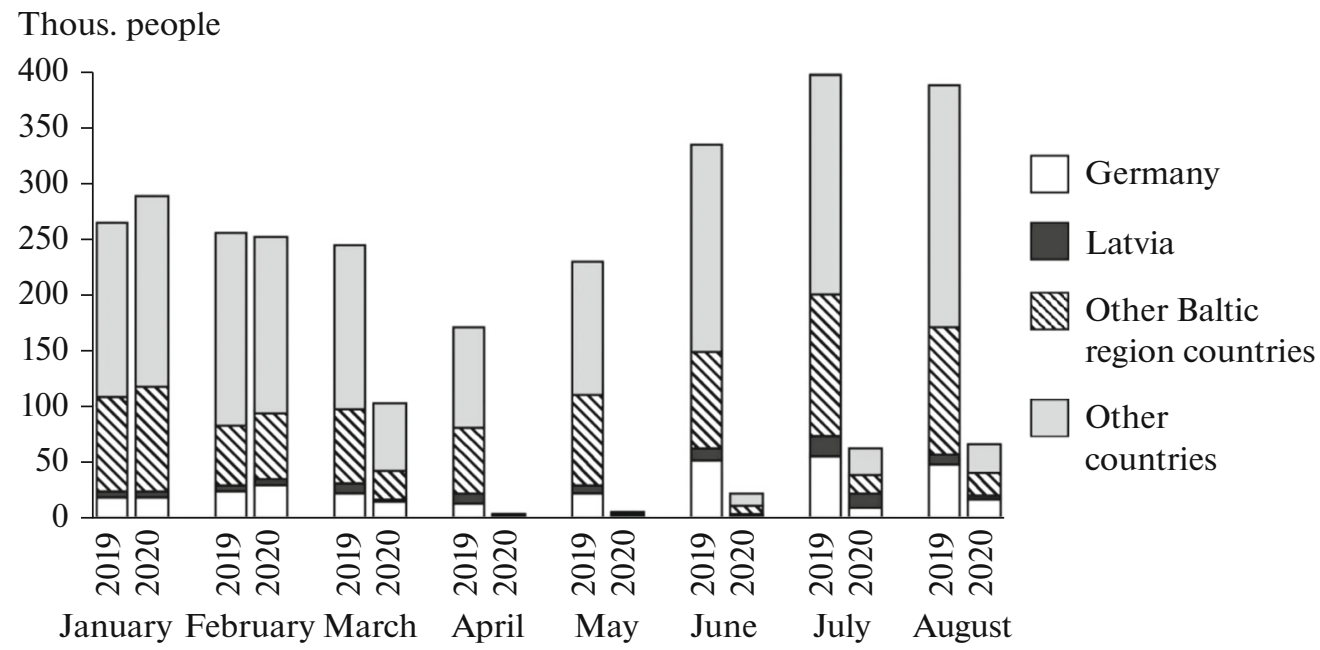

Fig. 3. Changes in structure of inbound tourist flow to Finland in first eight months of 2020 compared to same period of 2019.

tourist flow to Finland in the first eight months of 2020 versus the same period in 2019.

The recovery of inbound tourist traffic in Finland is much slower, both due to more stringent restrictions on entry (including for citizens of some EU countries with an unfavorable epidemiological situation) and to the rather large volume of tourist traffic in 2019 (in absolute values), which owing to a significant reduction in international air traffic cannot quickly recover.

The general drop in tourist traffic in July was $85 \%$. In July, the smallest decrease in tourist traffic was from Norway $(-33 \%)$; most Norwegian tourists in July came from two northern regions: Lapland and Northern Ostrobothnia. Consequently, the role of cross-border links between Finland and Norway remains quite high. The likely reason for this anomaly is lower prices for goods in Finland. In August 2020, this was no longer observed: the flow of tourists from Norway noticeably decreased. Tourist flow from Germany, which in 2019 ranked third in terms of inbound tourist flow after Russia and Sweden and in which the epidemiological situation, according to Finland, is comparatively more favorable, is also slowly recovering, although in absolute terms it is still far from the 2019 level. Tourist flows from Russia and Sweden have not yet shown recovery, since the border with Russia remains closed to tourists and there is still a mandatory two-week quarantine for Swedish citizens. 


\section{CONCLUSIONS}

Tourist traffic data for the first eight months of 2020 available as of the time of this article allows us to draw several conclusions.

First, tourism in Estonia and Finland went through a rather difficult period of spring quarantine, and recovery in the summer began with domestic tourism, which proceeded quite quickly. The request for rest of the citizens of these countries has been fully preserved, despite sanitary restrictions. Inbound tourism is still artificially limited both by the authorities of these countries and the general requirements of the European Union. With the sharp decline in the average range of tourist travel, growth begins with travel within the home country.

Second, the best dynamics are demonstrated by neighboring countries, the adjacent territories of which are part of the cross-border tourist and recreational regions. Whereas stringent restrictions on border crossing are not in effect (as, e.g., with the Russian Federation), tourism within cross-border tourist and recreational regions is recovering faster than tourist exchange with other countries.

Thus, the experience of restoring inbound tourism in Finland and Estonia, albeit temporarily (in July and August 2020), indicates a faster recovery of cross-border tourism than tourist flows with other, more geographically remote states. This conclusion gives hope for a fairly quick recovery of cross-border tourist exchange between Russia and neighboring countries once tourists are again allowed to cross state borders.

Although the second wave of the COVID-19 pandemic, which began in the fall of 2020, will slow the recovery of the tourism industry, the general patterns identified as a result of the study should manifest themselves as a re-recovery of international tourism.

\section{CONFLICT OF INTEREST}

The authors declare no conflict of interest.

\section{REFERENCES}

Atamanchuk, Z.A., Development of international tourism in the context of the COVID-19 pandemic: trends and expectations, Biz. Inform, 2020, no. 5, pp. 94-99.

Butorov, S.A., Impact of the COVID-19 pandemic on the global tourism industry, Vestn. Mosk. Gos. Univ. Kul't. Iskusstv., 2020, no. 2 (94), pp. 116-125.

Chimiris, S.V., Impact of the COVID-19 coronavirus pandemic crisis on the Russian tourism industry and its prospective development, Evraziiskii Yuridicheskii Zh., 2020, no. 6 (145), pp. 446-447.

Chuchenkova, O.A., Geography of international inbound tourist flows in Estonia in 2004-2018, Vestn. Pskov. Gos. Univ., Ser. Estestv. Fiz.-Matem. Nauki, 2019, no. 14, pp. 55-66.

Daniela, M. and Smaranda, T., The International Tourism and the COVID-19 Pandemic - Present and Perspec- tives, “Ovidius” University Ann. Econ. Sci. Ser., 2020, vol. 20, no. 1 , pp. 433-438.

Golomidova, E.S., Cross-border touristic and recreational Narvsky microregion: special features of formation and development perspectives, Pskov. Regionol. Zh., 2018, no. 3 (35), pp. 108-115.

Korinth, B. and Ranasinghe, R., COVID-19 pandemic's impact on tourism in Poland in March 2020, GeoJ.Ttourism Geosites, 2020, vol. 31, no. 3, pp.987990.

https://doi.org/10.30892/gtg.31308-531

Kropinova, E.G., Transgranichnye turistsko-rekreatsionnye regiony na Blatike (Cross-Border Touristic and Recreational Baltic Regions), Kaliningrad: Balt. Fed. Univ. im. I. Kanta, 2016.

Kropinova, E.G. and Stankus, K., The impact of COVID-19 on the development of psychological tourism, Trudy Mezhdunarodnoi nauchno-prakticheskoi konferentsii "Gumanitarnoe $i$ sotsial'no-nauchnoe znanie: teoreticheskie issledovaniya i prakticheskie razrabotki" (Proc. Int. Sci.-Pract. Conf. "Humanitarian and Social-Scientific Knowledge: Theoretical Studies and Practice"), Moscow, 2020, pp. 192-199.

Leonidova, E.G., Problems in touristic industry as a factor of regional development under impact of the COVID-19 pandemic, Aktual. Probl. Ekon. Prava, 2020, vol. 14, no. 3, pp. 624-637.

Leushina, O.V. and Zotova, E.G., Development of the tourism sector in a pandemic conditions, Materialy IV Mezhdunarodnogo kruglogo stola "Ekonomika $i$ menedzhment $v$ XXI veke: Informatsionnye tekhnologii, biotekhnologii, fizkul'tura i sport" (Proc. IV Int. Roundtable Discussion "Economy and Management in 21st Century: Information Technologies, Biotechnologies, Physical Training, and Sports"), Moscow, 2020, pp. 110-111.

Linguryan, N.V. and Kalinkina, S.A., Tourism in Russia during and after the coronavirus pandemic, Materialy Mezhdunarodnoi nauchno-prakticheskoi konferentsii "Proryvnye ekonomicheskie reformy $v$ usloviyakh riska $i$ neopredelennosti" (Proc. Int. Sci.-Pract. Conf. "Breakthrough Economic Reforms in Risk and Uncertainty Conditions"), Sterlitamak, 2020, pp. 65-67.

Loguntsova, I.V., The tourism industry in the conditions of coronavirus pandemic: challenges and prospects, Gos. Upr., 2020, no. 80, pp. 49-65.

https://doi.org/10.24411/2070-1381-2019-10063

Makrinova, E.I., Lysenko, V.V., and Rybochkina, E.A., An active governmental policy to support the tourism industry in a crisis, Vestn. Belgorod. Univ. Koop., Ekon. Prava, 2020, no. 4 (83), pp. 27-41. https://doi.org/10.21295/2223-5639-2020-4-27-41

Manakov, A.G. and Golomidova, E.S., Estimating the development of the Latvian-Estonian-Russian transboundary tourism and recreational region, Balt. Reg., 2018, vol. 10 , no. 1 , pp. $130-141$.

https://doi.org/10.5922/2079-8555-2018-1-8

Manakov, A.G. and Ivanov, I.A., Dynamics of tourist exchange between Russia and neighboring countries of Northern Europe in 2004-2018, Pskov. Regionol. Zh., 2019 , no. 3 (39), pp. $128-144$.

https://doi.org/10.37490/S221979310011951-9 
Manakov, A.G., Kondrat'eva, S.V., and Terenina, N.K., The formation degree of cross-border touristic-recreational regions on the Karelian territory of the RussianFinnish border, Balt. Reg., 2020, vol. 12, no. 2, pp. 140-152.

https://doi.org/10.5922/2079-8555-2020-2-9

Manakov, A.G., Chuchenkova, O.A., and Ivanov, I.A., Geography of tourism in Estonia within the framework of cross-border touristic-recreational region formation, Pskov. Regionol. Zh., 2019, no. 4 (40), pp. 80-95. https://doi.org/10.37490/S221979310010191-3

Polukhina, A.N., Tourism in the crisis epoch: analysis and perspectives, Innovatsionnoe Razvit. Ekon., 2020, no. 2 (56), pp. 286-292.

Rogerson, C.M. and Rogerson, J.M., COVID-19 tourism impacts in South Africa: government and industry responses, GeoJournal Tourism Geosites, 2020, vol. 31, no. 3, pp. 1083-1091.

https://doi.org/10.30892/gtg.3311332211-554444

Rysaeva, M.A. and Kabirov, I.S., Restart of Russian tourism: collapse caused by COVID-19, Vestn. Nats. Akad. Turizma, 2020, no. 3 (55), pp. 20-23.
Simonyan, G.A. and Saryan, A.A., Impact of coronavirus pandemic on tourism, Sovrem. Nauchn. Mysl', 2020, no. 2 , pp. $158-164$.

Stepanova, S.V., Cross-border tourism in the Russian Northwest: general trends and features of development, Balt. Reg., 2014, no. 3 (21), pp. 109-120.

Stepanova, S.V., Factors in the development of cross-border tourism in the adjacent areas of Russia and Finland, Pskov. Regionol. Zh., 2019, no. 4 (40), pp. 106-114. https://doi.org/10.37490/S221979310011766-5

Stepanova, S.V. and Shulepov, V.I., Tourism development in cross-border regions of Northwest Russia: general trends and features, Econ., Manage., Inf., Technol., 2016, vol. 4, no. 3, pp. 27-32.

Telicheva, E.G. and Chernov, V.A., Sustainable tourism development: content review of the tourism market during a coronavirus pandemic, Nauchno-Tekh. Ekon. Sotrudn. Stran ATP XXI Veke, 2020, vol. 2, pp. 136-140.

Zubarevich, N.V. and Safronov, S.G., Russian regions in the acute phase of the coronavirus crisis: differences from previous economic crises of the 2000s, Reg. Res. Russ., 2020, vol. 10, no. 4, pp. 443-453. https://doi.org/10.1134/S2079970520040115 